\title{
Heterotrophic denitrification at extremely high salt and pH by haloalkaliphilic Gammaproteobacteria from hypersaline soda lakes
}

\author{
A. A. Shapovalova $\cdot$ T. V. Khijniak • \\ T. P. Tourova · G. Muyzer · D. Y. Sorokin
}

Received: 25 March 2008/Accepted: 11 April 2008/Published online: 2 May 2008

(C) The Author(s) 2008

\begin{abstract}
In this paper we describe denitrification at extremely high salt and $\mathrm{pH}$ in sediments from hypersaline alkaline soda lakes and soda soils. Experiments with sediment slurries demonstrated the presence of acetateutilizing denitrifying populations active at in situ conditions. Anaerobic enrichment cultures at $\mathrm{pH} 10$ and $4 \mathrm{M}$ total $\mathrm{Na}^{+}$with acetate as electron donor and nitrate, nitrite and $\mathrm{N}_{2} \mathrm{O}$ as electron acceptors resulted in the dominance of Gammaproteobacteria belonging to the genus Halomonas. Both mixed and pure culture studies identified nitrite and $\mathrm{N}_{2} \mathrm{O}$ reduction as rate-limiting steps in the denitrification process at extremely haloalkaline conditions.
\end{abstract}

Keywords Denitrification - Soda lakes . Haloalkaliphilic · Halomonas $\cdot$ Alkalispirillum

Communicated by T. Matsunaga.

The GenBank accession numbers of the 16S rRNA gene sequences obtained in this study are EU447163-EU447170.

Electronic supplementary material The online version of this article (doi:10.1007/s00792-008-0166-6) contains supplementary material, which is available to authorized users.

A. A. Shapovalova - T. V. Khijniak - T. P. Tourova .

D. Y. Sorokin $(\square)$

Winogradsky Institute of Microbiology,

Russian Academy of Sciences,

Prospect 60-let Octyabrya 7/2,

117811 Moscow, Russia

e-mail: soroc@inmi.host.ru; d.y.sorokin@tudelft.nl

G. Muyzer · D. Y. Sorokin

Department of Biotechnology, Delft University of Technology,

Julianalaan 67, 2628 BC Delft, The Netherlands

\section{Introduction}

Denitrification is an important process of oxidation of organic and inorganic compounds in natural and engineered anoxic environments. Regarding its energy efficiency, it is following aerobic respiration and, therefore should be well represented at extreme conditions demanding the efficient energy conservation, such as haloalkaline lakes, saline soils and highly saline industrial wastewater (Oren 1999). While it is indeed well documented for moderate haloalkaline conditions (i.e., a $\mathrm{pH}$ around 9 and a salt concentration up to $2 \mathrm{M} \mathrm{Na}^{+}$), little is known on the possibility of denitrification at extremely haloalkaline conditions, such as those present in hypersaline alkaline soda lakes (i.e., a pH up to 11 and a salt concentration up to $4 \mathrm{M} \mathrm{Na}^{+}$). Denitrification at moderate haloalkaline conditions has been shown previously for several members of the Gammaproteobacteria, both with chemolithoautotrophic metabolism, such as sulfur-oxidizing Thioalkalivibrio spp. (Sorokin et al. 2001; Sorokin and Kuenen 2005) and obligate heterotrophs, such as Halomonas spp. (Berendes et al. 1996; Mormille et al. 1999; Peyton et al. 2001; Romano et al. 2005; Boltyanskaya et al. 2004, 2007). The only example of active denitrification at extremely haloalkaline conditions has recently been demonstrated in experiments with sediment slurries from Mono Lake (CA, USA). The maximum activity of nitrate reduction with glucose was found at a salt concentration between 1.6 and $2.3 \mathrm{M}$ $\mathrm{NaCl}$, pH 9.8 (Kulp et al. 2007), which was above the natural salinity of the lake (i.e., $1.5 \mathrm{M}$ ).

Here we report the results of denitrification at extremely haloalkaline conditions in sediments of hypersaline alkaline lakes and soda soils and the characterization of the bacteria responsible for this process. 


\section{Methods}

Soda lake characteristics and sampling

Surface sediment samples $(0-10 \mathrm{~cm})$ were obtained from hypersaline soda lakes in northeastern Mongolia, Kulunda Steppe (Altai, Russia), Kenya (Lakes Magadi and Bogoria) and Wadi al Natrun in Egypt. The $\mathrm{pH}$ of the brines varied from 9.2 to 10.6 , the total salt concentration, from 20 to $400 \mathrm{~g} \mathrm{l}^{-1}$, and the total (soluble) alkalinity, from 0.05 to 3.0 M. More information about the sites can be found in Sorokin and Kuenen (2005), Taher (1999) and Duckworth et al. (1996). In addition, several samples of saline soda soils were collected in Kulunda Steppe and NE Mongolia. Measurements of the potential denitrifacation rates (DR) in the sediment slurry experiments were conducted in July 2007 for three lakes in Kulunda Steppe. Lake Picturesque is a low productivity lake with gray clay sediments without free sulfide (total salt $=102 \mathrm{~g} \mathrm{l}^{-1} ; \mathrm{pH}=10.20$; soluble carbonate alkalinity $=1.34 \mathrm{M}$ ). Lakes Tanatar-5 and Bitter-1 are high productivity lakes with black sulfidic sediments (total salt content of the brines $=65$ and $180 \mathrm{~g} \mathrm{l}^{-1}, \mathrm{pH}=10.35$ and 10.53 , and total alkalinity $=0.77$ and $2.95 \mathrm{M}$, respectively). For the enrichments, we mixed 5-10 samples from each lake or soil to form a single inoculum for each geographic region.

The potential DR was measured in the laboratory with sediment slurries. For this, the sediments were either diluted with two parts of the lake water (i.e., "natural slurry") or first were separated from the pore brines by centrifugation and suspended in various buffers to study the effect of $\mathrm{pH}$ and salt (see below) on the potential DR of the natural denitrifying populations. In some cases (i.e., at the lowest and highest $\mathrm{pH}$ range), it was necessary to adjust the $\mathrm{pH}$ to the desired values before the experiment. The experiments were conducted in 12-ml serum bottles closed with butyl rubber stoppers with $3 \mathrm{ml}$ slurry and $9 \mathrm{ml}$ gas phase consisted of $90 \%(\mathrm{v} / \mathrm{v})$ argon $/ 10 \%(\mathrm{v} / \mathrm{v})$ acetylene. In experiments with $\mathrm{N}_{2} \mathrm{O}$ as the electron acceptor, acetylene was omitted. After the end of each experiment, the final $\mathrm{pH}$ values in the slurries were measured.

\section{Cultivation of bacteria}

Anaerobic enrichments and subsequent cultivation of isolated strains were performed at $30^{\circ} \mathrm{C}$ using a highly buffered alkaline saline mineral base medium containing $0.6-4.0 \mathrm{M} \mathrm{Na}^{+}$, of which $50 \% \mathrm{Na}^{+}$was present as $\mathrm{NaCl}$ and $50 \%$ as sodium carbonate/bicarbonate buffer $\mathrm{pH} 10.1$ (2 M total $\mathrm{Na}^{+}$). A measure of $0.5 \mathrm{~g} \mathrm{l}^{-1}$ of $\mathrm{K}_{2} \mathrm{HPO}_{4}$ served as $\mathrm{P}$ and $\mathrm{K}$ source. After sterilization, the medium was supplemented with $1 \mathrm{mM} \mathrm{MgSO} \cdot 7 \mathrm{H}_{2} \mathrm{O}, 1 \mathrm{ml} \mathrm{l}^{-1}$ trace metal solution (Pfenning and Lippert 1966), $20 \mathrm{mM}$ sodium acetate, $0.1 \mathrm{~g} \mathrm{l}^{-1}$ yeast extract and 5-20 $\mathrm{mM}$ nitrate or nitrite or $40 \mathrm{mM} \mathrm{N} \mathrm{N}_{2} \mathrm{O}$. Routine anaerobic cultivation was performed in 100-ml serum bottles with $80 \mathrm{ml}$ medium/ $20 \mathrm{ml}$ argon for nitrate/nitrite cultures, and $50 \mathrm{ml}$ medium/ $50 \mathrm{ml} \mathrm{N} \mathrm{N}_{2} \mathrm{O}$ for $\mathrm{N}_{2} \mathrm{O}$ cultures. Solid alkaline medium with a final salt concentration of $2 \mathrm{M} \mathrm{Na}^{+}$was prepared by $1: 1$ mixing of $4 \%(\mathrm{w} / \mathrm{v})$ agar (Noble, Difco) and the $4 \mathrm{M} \mathrm{Na}^{+}$ liquid medium (see above) at $50^{\circ} \mathrm{C}$. After inoculation, the plates were incubated in closed jars under $100 \%$ (v/v) argon or $90 \%(\mathrm{v} / \mathrm{v})$ argon $/ 10 \% \mathrm{~N}_{2} \mathrm{O}$ atmosphere in presence of the oxygen-scavenging catalyzer (Oxoid).

The $\mathrm{pH}$ dependence of denitrifying activity was examined at $0.6-2.0 \mathrm{M} \mathrm{Na}^{+} / 0.05 \mathrm{M} \mathrm{K}^{+}$, using the following buffers: for $\mathrm{pH}$ 7-8, 0.1 M HEPES and NaCl; for $\mathrm{pH} 8.5-$ 11, a mixture of sodium bicarbonate/sodium carbonate containing $0.1 \mathrm{M} \mathrm{NaCl}$. Incubation resulted in a shift of initial $\mathrm{pH}$ values, especially in highly alkaline region. Therefore, final $\mathrm{pH}$ values were taken to indicate suitable range for growth and activity. To study the influence of salt concentration on growth, mineral bases containing 0.1 and 4.0 $\mathrm{M}$ of total $\mathrm{Na}^{+}$at $\mathrm{pH} 10$ were mixed in different proportions.

\section{Analytical procedures}

Nitrite was analyzed by diazotation method according to Gries-Romijn-van Eck (1966). Nitrate analysis was complicated by extremely high alkalinity of the samples. Therefore, a most sensitive colorimetric method was chosen for the analysis on the basis of Szechrome NAS reagent (Polysciences, Inc., Warrington, PA) with the detection limit of $10 \mu \mathrm{M}$. This allowed the dilution of the brines by at least 100 times. $\mathrm{N}_{2} \mathrm{O}$ in the gas phase was analyzed by the gas chromatography using Fison Instruments chromatograph, Poropaq Q column and ${ }^{63} \mathrm{Ni}$-electron capture detector with a 6-port valve assembly activated pneumatically to vent column effluent after elution of nitrous oxide to avoid contamination of the detector by acetylene. The temperature of injector, column and detector was 100, 40 and $350^{\circ} \mathrm{C}$, respectively, the carrier gas was $\mathrm{N}_{2}$ at $10 \mathrm{ml} \mathrm{min}^{-1}$. Cell protein was measured after alkaline hydrolysis by the Lowry method (Lowry 1951). Phase contrast microphotographs were obtained with a Zeiss Axioplan Imaging 2 microscope (Göttingen, Germany). Comparison of the total cell proteins by SDS-PAGE was done according to Laemmli (1970).

Genetic and phylogenetic analysis

The isolation of the DNA and determination of the $\mathrm{G}+\mathrm{C}$ content of the DNA was performed according to Marmur (1961) and Marmur and Doty (1962). The DNA-DNA hybridization was performed by optical reassociation 
according to De Ley (1970). Genomic DNA for phylogenetic analysis was extracted from the cells using the UltraClean Soil DNA Extraction Kit (MoBio Laboratories, USA), following the manufacturer's instructions. The nearly complete $16 \mathrm{~S}$ rRNA gene was obtained from pure cultures using general bacterial primers 11F-1492R (Lane 1991). The 16S rRNA gene PCR products were purified from low-melting agarose using the Wizard PCR-Prep kit (Promega, USA). Sequencing was performed using Big Dye Terminator v.3.1 sequencing reaction kit on an ABI 3730 DNA automatic sequencer (Applied Biosystems, Inc.,USA). The sequences were aligned with those from GenBank using CLUSTALW. The 16S rRNA gene sequences were first compared to sequences stored in the GenBank database using BLAST search tool. Phylogenetic trees were reconstructed with four different algorithms using the TREECONW software package (van de Peer and de Wachter 1994). Pair wise evolutionary distances (expressed as estimated changes per 100 nucleotides) were computed using Jukes and Cantor (1969) method. A
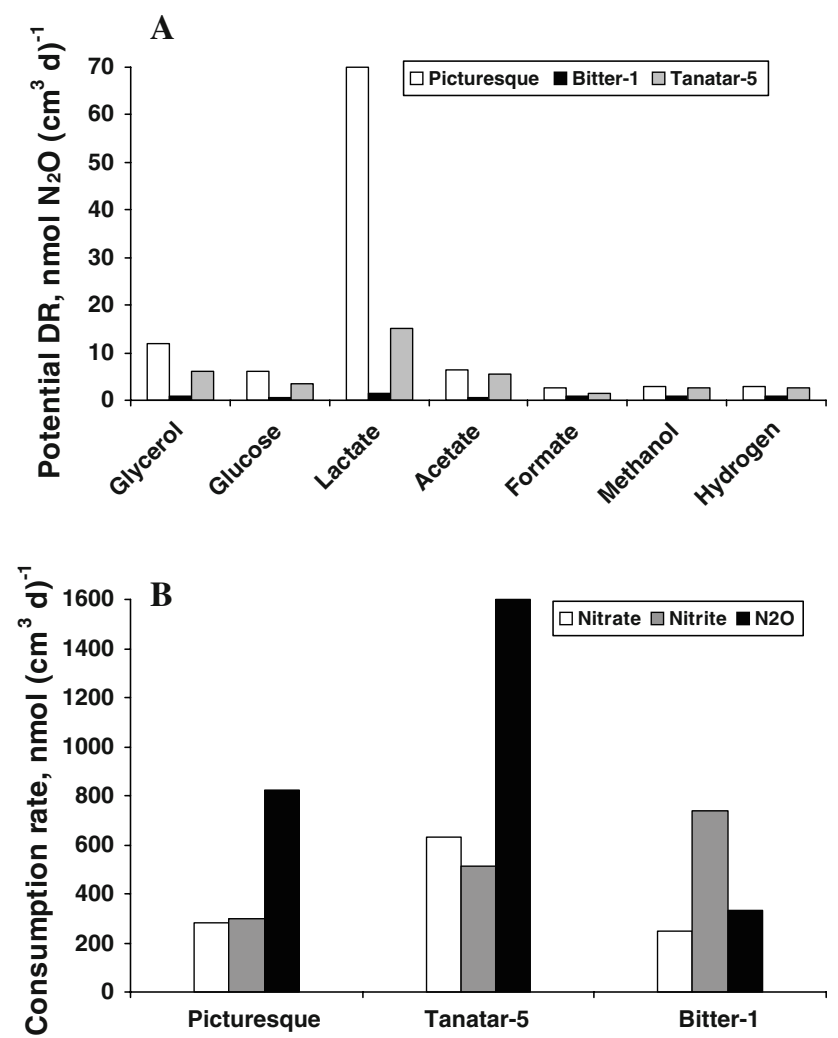

Fig. 1 Potential denitrification activity in sediments of hypersaline soda lakes in Kulunda Steppe (Altai, Russia). a Potential nitrate $\left(2 \mathrm{mM}\right.$ ) reduction to $\mathrm{N}_{2} \mathrm{O}$ in natural sediment slurries with different electron donors $(4 \mathrm{mM})$. b Reduction of different nitrogen oxides in the presence of $4 \mathrm{mM}$ acetate in natural sediments. c, $\mathbf{d}$ Influence of $\mathrm{pH}$ (at $0.6 \mathrm{M}$ total $\mathrm{Na}^{+}$) and soda (at $\mathrm{pH} 10$ ), respectively, on nitrate resulting phylogenetic tree was constructed by the neighbor-joining method.

\section{Results and discussion}

Potential DR in sediments of hypersaline soda lakes from Kulunda Steppe

The potential DR measurements in the sediment slurries amended with nitrogen oxides and electron donors revealed highest $\mathrm{N}_{2} \mathrm{O}$ formation in a less productive lake with lactate as the electron donor (Fig. 1a), although nitrate consumption was faster in the sediments from the other two, highly productive, lakes. It is possible, that the acetylene block was not efficient in the latter, because of high sulfide concentrations in the sediments (Knowles 1990). At least the potential for nitrite and $\mathrm{N}_{2} \mathrm{O}$ reduction was either equal or even higher in the eutrophic lake sediments (Fig. 1b). The influence of $\mathrm{pH}$ and salt on the potential DR
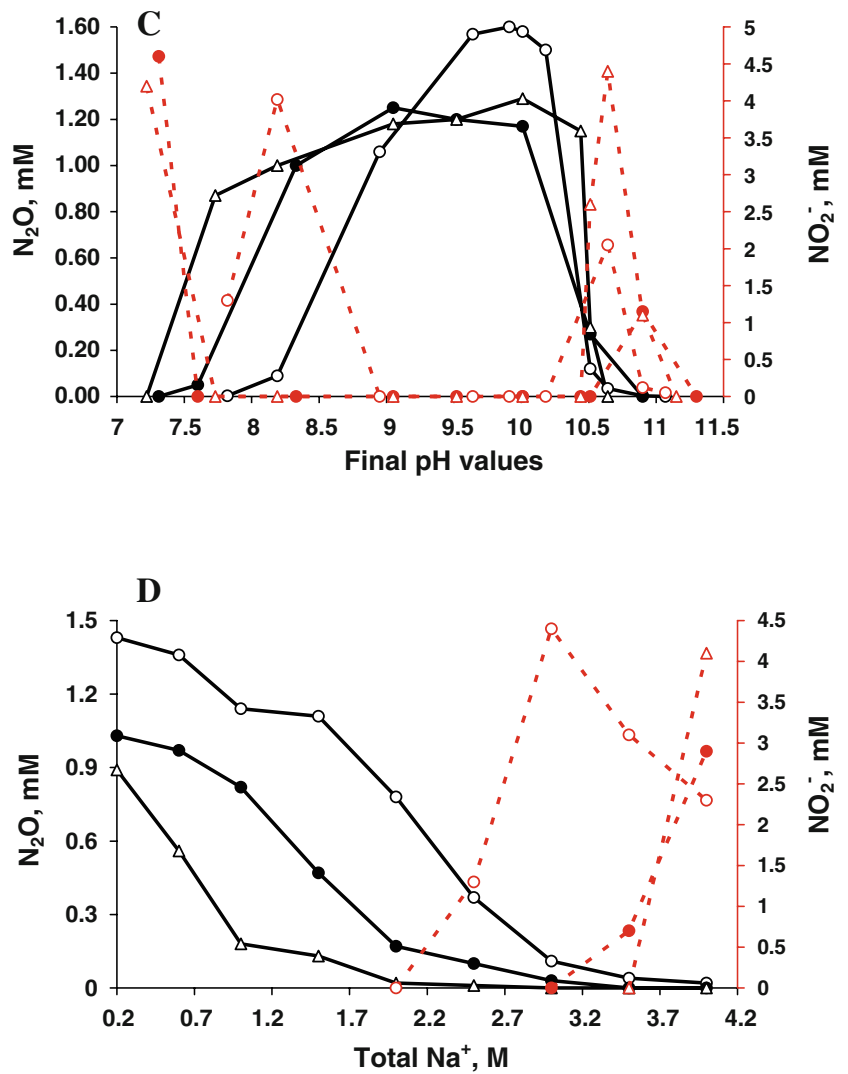

reduction with $4 \mathrm{mM}$ acetate in sediments freed from the pore waters and suspended in salt buffers. The solid lines depict $\mathrm{N}_{2} \mathrm{O}$ formation in the presence of acetylene and the dashed lines depict nitrite formation; open circles lake Picturesque; closed circles lake Tanatar-5; open triangles lake Bitter-1 
was examined with acetate as electron donor and nitrate as electron acceptor. The experiments clearly demonstrated an obligate alkaliphilic nature (Fig. 1c), but only a moderate salt tolerance (Fig. 1d) of the denitrifying populations in all three lakes. A common trend can also be seen for both $\mathrm{pH}$ and salt extremes where most of the nitrate added was reduced only to the level of nitrite. This happened at a pH below 8 and above 10.5 and at salinity above $2.5-3 \mathrm{M}$ $\mathrm{Na}^{+}$.

Enrichment and isolation of bacterial strains

Anaerobic enrichments with acetate as electron donor from six combined sediment and soil samples at $\mathrm{pH} 10$ and $4 \mathrm{M}$ $\mathrm{Na}^{+}$were most active with nitrate as electron acceptor, although significant accumulation of nitrite occurred at nitrate concentrations above $5 \mathrm{mM}$, similar to that found in the sediment slurry experiments (see above). In several cases a lower salinity was used, resulting in a less prominent (at $2.3 \mathrm{M} \mathrm{Na}^{+}$) or complete absence (at $0.6 \mathrm{M} \mathrm{Na}^{+}$) of nitrite accumulation. Incubations with nitrite also gave positive results when the nitrite concentration was below $10 \mathrm{mM}$. With $\mathrm{N}_{2} \mathrm{O}$ as an acceptor, activity was observed in all cultures, but only in two cases it was stable during further transfers. Overall, 15 pure cultures of acetate-utilizing haloalkaliphilic denitrifiers were obtained from six mixed samples (Table 1). Fourteen strains were motile rods of variable cell size and a single strain AGDZ, enriched and isolated with $\mathrm{N}_{2} \mathrm{O}$, was a motile spirillum

Table 1 Isolates from hypersaline alkaline habitats capable of denitrification at 2-4 $\mathrm{M}$ total $\mathrm{Na}^{+}$and $\mathrm{pH} 10$

\begin{tabular}{lllll}
\hline Strains & Source & $\begin{array}{l}\text { Salinity } \\
\left(\mathrm{M} \mathrm{Na}^{+}\right)\end{array}$ & Acceptor & $\begin{array}{l}\text { Phylogenetic } \\
\text { affiliation }\end{array}$ \\
\hline AGD 1 & Wadi Natrun & 2.3 & $\mathrm{NO}_{3}{ }^{-}$ & Halomonas \\
AGD 15 & lakes & 4.0 & $\mathrm{NO}_{3}{ }^{-}$ & Halomonas \\
AGD 12 & & 4.0 & $\mathrm{NO}_{2}{ }^{-}$ & Halomonas \\
AGDZ & & 4.0 & $\mathrm{~N}_{2} \mathrm{O}$ & Alkalispirillum \\
AGJ 1-3 & Kenyan lakes & 0.6 & $\mathrm{NO}_{3}{ }^{-}$ & Halomonas \\
AGD 5 & & 4.0 & $\mathrm{NO}_{2}{ }^{-}$ & Halomonas \\
AGD 7 & & 4.0 & $\mathrm{NO}_{3}{ }^{-}$ & Halomonas \\
AGD 2 & Mongolian lakes & 4.0 & $\mathrm{NO}_{3}{ }^{-}$ & Halomonas \\
AGD 3 & & 4.0 & $\mathrm{NO}_{2}{ }^{-}$ & Halomonas \\
AGD 13 & & 4.0 & $\mathrm{~N}_{2} \mathrm{O}^{-}$ & Halomonas \\
AGD 8-1 & Mongolian soils & 2.3 & $\mathrm{NO}_{3}{ }^{-}$ & Halomonas \\
AGD 8-2 & & 2.3 & $\mathrm{NO}_{2}{ }^{-}$ & Halomonas \\
AGD 8-3 & & 4.0 & $\mathrm{NO}_{3}{ }^{-}$ & Halomonas \\
AGDK 5 & Kulunda Steppe & 4.0 & $\mathrm{NO}_{3}{ }^{-}$ & Halomonas \\
AGDKS & Kulunda Steppe & 4.0 & $\mathrm{NO}_{3}{ }^{-}$ & Halomonas \\
\hline & soils & & & \\
\hline
\end{tabular}

(Supplementary Figure 1). A commonly observed feature of the cell morphology in most of the rod-shaped isolates was the formation of large empty patches (see for example Supplementary Fig. 1a).

The DNA-DNA hybridization between and the total protein profiling of the rod-shaped isolates (Supplementary Figure 2) demonstrated the presence of three different clusters, two of them including the lake isolates and the third one the Mongolian soil isolates. The DNA relatedness within the clusters was 50-90\% and between the clusters was below $25 \%$. The phylogenetic analysis based on $16 \mathrm{~S}$ rRNA gene sequences placed the rod-shaped isolates into the genus Halomonas and the spiral-shaped strain AGDZ into the genus Alkalispirillum, both in the Gammaproteobacteria (Fig. 2). The properties of Alkalispirillum sp. strain AGDZ have been described in detail elsewhere (Sorokin et al. 2006). The rod-shaped lake isolates clustered with two haloalkaliphilic Halomonas species (H. mongoliensis and H. campisalis) capable of denitrification at moderate salinity, while the soil isolates formed

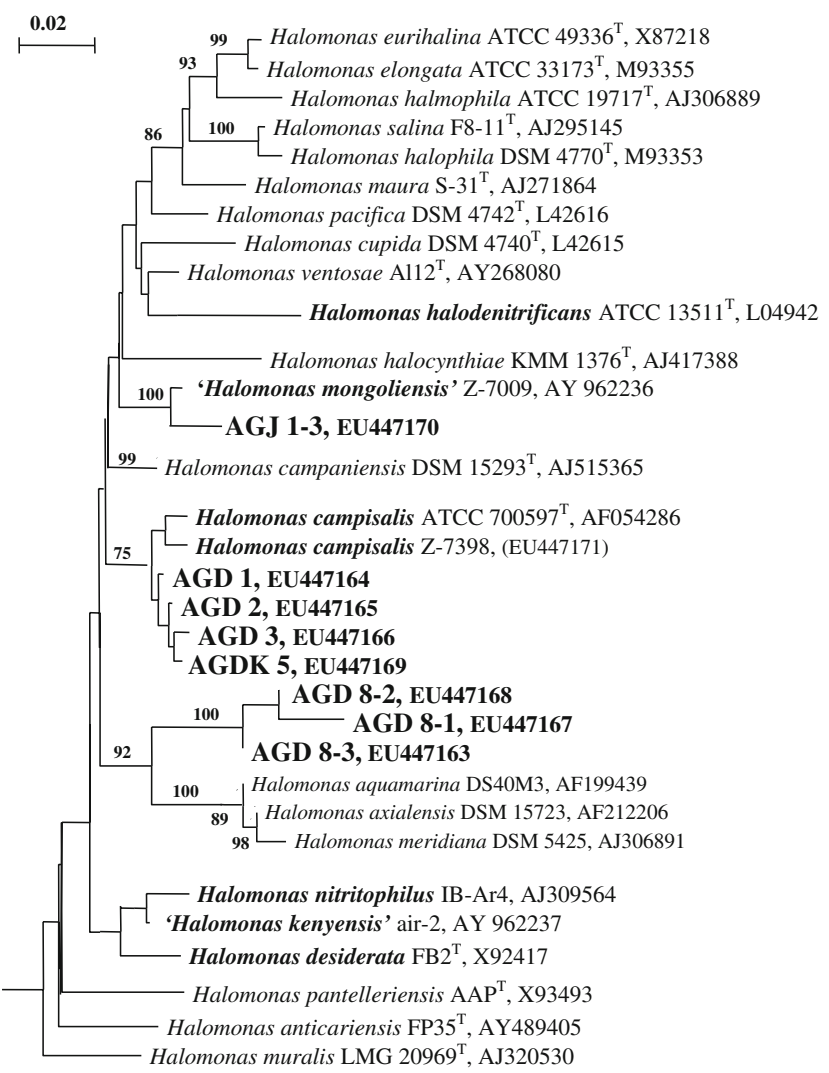

Fig. 2 Phylogenetic affiliation based on 16S rDNA gene sequence analysis of the haloalkaliphilic denitrifying isolates from hypersaline soda lakes within the genus Halomonas. The tree was reconstructed using maximum likelihood method and filter. The percentage of bootstraps was derived from 1,000 resampling using neighbor-joining algorithm, only values greater than 70 are given. Denitrifying species are printed in bold type 
another, well separated group, which probably represents a novel species.

Influence of salts and $\mathrm{pH}$ on the growth and activity of Halomonas sp. strain AGD 3

All isolated Halomonas strains, in contrast to any previously described haloalkaliphilic denitrifiers, were capable of anaerobic growth with nitrate and nitrite, and some also with $\mathrm{N}_{2} \mathrm{O}$ in saturated sodium carbonate brines (4 $\mathrm{M}$ total $\mathrm{Na}^{+}$) at $\mathrm{pH}$ 10. However, at such high salinity, the anaerobic growth with nitrate was very slow and high intermediate product accumulation was evident, which was similar to that observed in the sediment slurry incubations. This is illustrated with an example of strain AGD 3 (Fig. 3a). Nitrite and $\mathrm{N}_{2} \mathrm{O}$ did not accumulate at significant level only at salinity below $1 \mathrm{M} \mathrm{Na}^{+}$. Similar to anaerobic growth with nitrate, a sharp decrease in the growth rate was also observed with $\mathrm{N}_{2} \mathrm{O}$ and oxygen as the electron acceptors but, strangely, not with nitrite (Fig. 3b). High level of nitrite accumulation during anaerobic growth with nitrate at high salt suggested that the nitrite reduction step was a bottleneck in the denitrification process. However, when nitrate was not present, strain AGD 3 was growing optimally with nitrite at $3 \mathrm{M} \mathrm{Na}^{+}$(Fig. 3b). To clarify the situation, activity experiments with washed cells of strain AGD 3 grown at $3 \mathrm{M} \mathrm{Na}^{+}$with nitrate were conducted. The results confirmed a high salt dependence and a high salt optimum of the nitrite reduction step. In contrast, nitrate reductase was active within a very broad salinity range, while $\mathrm{N}_{2} \mathrm{O}$ reductase was the least salt tolerant (Fig. 3c). From these it can be concluded that difficulties in anaerobic growth with $\mathrm{N}_{2} \mathrm{O}$ and accumulation of the latter at extreme salinity in haloalkaliphilic Halomonas isolates were clearly connected to a low salt tolerance of the $\mathrm{N}_{2} \mathrm{O}$ reductase. In contrast, high nitrite accumulation during the anaerobic growth with nitrate might rather indicate a disconnected action of nitrate and nitrite reductases at extremely haloalkaline conditions (for example, by a competition for electrons).

Dithionite-reduced minus air-oxidized difference spectroscopy of the cell-free extract obtained from the cells of strain AGD 3 grown anaerobically with nitrate or nitrite indicated a possible presence of a cytochrome $c d_{1}$-type nitrite-reductase in its soluble fraction (alpha peaks at 551, 615 and $670 \mathrm{~nm}$; data not shown). In the cells grown either aerobically or anaerobically with $\mathrm{N}_{2} \mathrm{O}$, this component was not detectable.

Another interesting question was whether strain AGD 3, isolated from a typical soda lake habitat with domination of sodium carbonates in its brines would react differently on different sodium salts. This was tested with washed cells grown aerobically with acetate at $3 \mathrm{M}$ total $\mathrm{Na}^{+}$. Respiration tests clearly demonstrated a preference for sodium
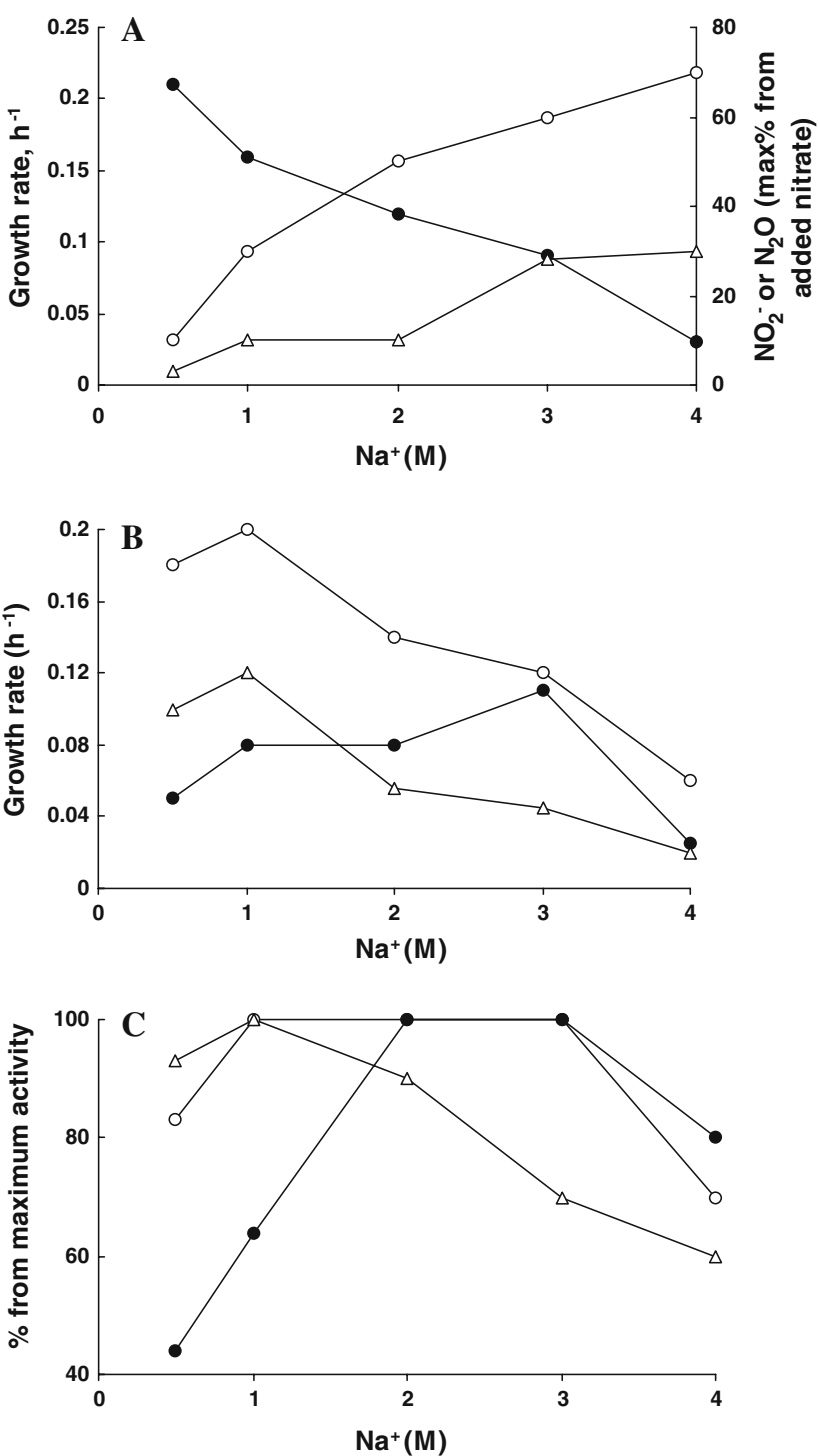

Fig. 3 Influence of soda concentration on anaerobic growth $(\mathbf{a}, \mathbf{b})$ and on activity of washed cells (c) in strain AGD 3 at pH 10 with acetate as the electron donor. a Anaerobic growth with nitrate: closed circles growth rate, open circles and triangles formation of nitrite and $\mathrm{N}_{2} \mathrm{O}$, respectively. b Influence of soda on aerobic (open circles), and anaerobic growth with nitrite (closed circles) and $\mathrm{N}_{2} \mathrm{O}$ (triangles). c Influence of soda on activity of reduction of nitrate (open circles), nitrite (closed circles) and $\mathrm{N}_{2} \mathrm{O}$ (triangles) by washed cells, grown anaerobically with nitrate at $3 \mathrm{M} \mathrm{Na}^{+}$

carbonate and sodium sulfate over sodium chloride (Fig. 4). Sodium carbonate and sodium sulfate are very similar in their physico-chemical properties (weakly dissociated electrolytes) in contrast to highly dissociated strong electrolyte sodium chloride. Apparently, this difference of ca. 2 times is important for bacteria thriving in soda brines. One of the reasons might be a lower osmotic demand for compatible solutes as has been demonstrated recently for chemolithoautotrophic "soda-philic" sulfur-oxidizing bacteria from soda lakes (Banciu et al. 2004, 2008). However, 


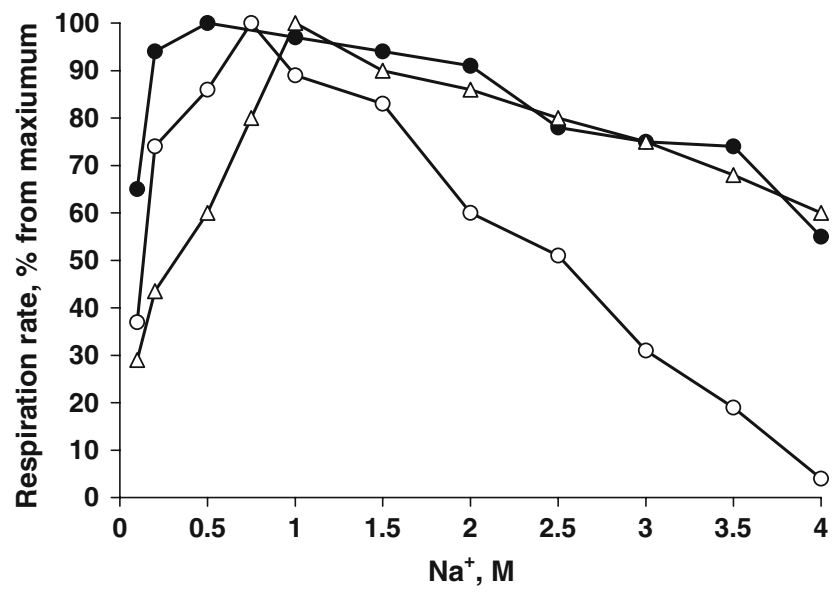

Fig. 4 Influence of sodium salts at $\mathrm{pH} 10$ on acetate-dependent respiration activity of washed cells of strain AGD 3. Open circles respiration in $\mathrm{NaCl}$, closed circles respiration in $\mathrm{Na}_{2} \mathrm{SO}_{4}$, triangles respiration in soda. One hundred percent activity was $250-350 \mathrm{nmol}$ $\mathrm{O}_{2} /(\mathrm{mg}$ protein $\min )$

this cannot explain such a preference on the level of activity of non-growing cells. Apparently, catabolic respiratory enzymes in the soda lake bacteria are better "tuned" to sodium carbonate.

The $\mathrm{pH}$ effect on different denitrification steps was investigated in washed cells of strain AGD 3 grown anaerobically with three different nitrogen oxides. The general response was very characteristic of obligate alkaliphiles, with virtually no activity at neutral $\mathrm{pH}$. On the other hand, the denitrifying activity was still possible within the extremely alkaline region ( $\mathrm{pH} 11-11.5)$, where growth was not possible, similar to that observed in various groups of chemolithoautotrophic bacteria from soda lakes (Sorokin and Kuenen 2005). From the three different reductases, the nitrite-reductase was the most alkalidependent with a $\mathrm{pH}$ optimum of 10.6-11.0. The $\mathrm{N}_{2} \mathrm{O}$ reductase was also extremely alkali-dependent with an optimum of $\mathrm{pH} \mathrm{10,} \mathrm{and} \mathrm{the} \mathrm{nitrate} \mathrm{reductase} \mathrm{was} \mathrm{only}$ moderately alkaliphilic with an optimum of pH 9 (Fig. 5).

Concluding, we were able to demonstrate denitrification by the native microbial populations in the sediments of hypersaline soda lakes, as well as by the pure cultures of haloalkaliphilic Gammaproteobacteria isolated from the hypersaline soda habitats. Among the cultivated strains, the facultatively anaerobic bacteria of the genus Halomonas were obviously dominating. They are alkaliphilic and extremely salt tolerant with a preference of sodium carbonate over sodium chloride. The anaerobic growth at extremely haloalkaline conditions was constrained mainly at the level of $\mathrm{N}_{2} \mathrm{O}$ reduction and also resulted in high intermediate nitrite accumulation despite the fact of high salt tolerance of nitrite reduction step. Such bacteria might have a role as a sink for acetate accumulating in anaerobic

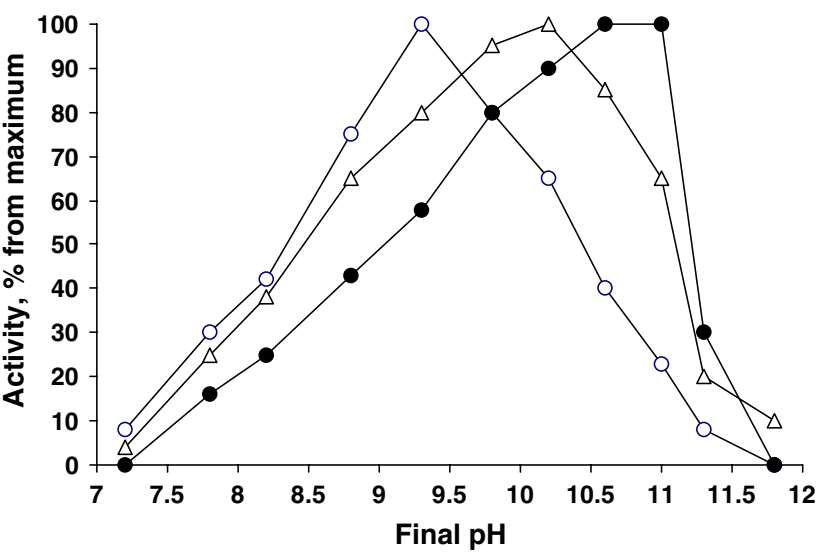

Fig. 5 Influence of $\mathrm{pH}$ on activity of denitrifying enzymes in washed cells of Halomonas strain AGD 3 grown at $2 \mathrm{M} \mathrm{Na}^{+}, \mathrm{pH} 10$. The cells were tested at $2 \mathrm{M} \mathrm{Na}^{+}$with $10 \mathrm{mM}$ acetate as the electron donor and $5 \mathrm{mM}$ of nitrate (nitrate-grown cells open circles), nitrite (nitritegrown cells closed circles) or $\mathrm{N}_{2} \mathrm{O}\left(\mathrm{N}_{2} \mathrm{O}\right.$-grown cells open triangles). The following buffer systems were used: for $\mathrm{pH} 7-8$, HEPES/NaCl; pH 8.5-11.5, $\mathrm{NaHCO}_{3} / \mathrm{Na}_{2} \mathrm{CO}_{3} ; \mathrm{pH} 12, \mathrm{Na}_{2} \mathrm{CO}_{3} / \mathrm{NaOH}$. Incubation time, $4 \mathrm{~h}$; cell concentration, $0.6 \mathrm{mg}$ protein $/ \mathrm{ml}$. One hundred percent activity: nitrate reductase $=240$, nitrite reductase $=190$ and $\mathrm{N}_{2} \mathrm{O}$ reductase $=150 \mathrm{nmol} /(\mathrm{mg}$ protein $\mathrm{min})$

sediments at hypersaline conditions (Oren 1995, 2001), assuming that nitrogen oxides are available. The source of nitrate in hypersaline habitats is still a question, since nitrification is apparently arrested at salinity above $1 \mathrm{M}$ $\mathrm{Na}^{+}$(Oren 1999; Sorokin and Kuenen 2005). Most probably, nitrate is entering from the surrounding soils and with the ground waters. The extremely salt tolerant alkaliphilic denitrifiers are also interesting as a possible tool in biological decontamination of acetate/nitrate-containing alkaline wastewater produced during the regeneration of ion-exchange columns (Clifford and Liu 1993).

Acknowledgments This work was supported by NWO-RFBR (47.011.2004.010), RFBR (07-04-00153) and by the Program of the Russian Academy of Sciences "Molecular and Cell Biology". We are grateful to A. Lysenko for conducting the DNA-DNA hybridization experiments and to B. Jones for supplying samples from Kenyan soda lakes.

Open Access This article is distributed under the terms of the Creative Commons Attribution Noncommercial License which permits any noncommercial use, distribution, and reproduction in any medium, provided the original author(s) and source are credited.

\section{References}

Banciu H, Sorokin DY, Muyzer G, Kleerebezem R, Galinski EA, Kuenen JG (2004) Thioalkalivibrio halophilus sp. nov, a novel obligately chemolithoautotrophic facultatively alkaliphilic and extremely salt-tolerant sulfur-oxidizing bacterium from a hypersaline alkaline lake. Extremophiles 8:325-334 
Banciu H, Sorokin DY, Tourova TP, Galinski EA, Muntyan MS, Kuenen JG, Muyzer G (2008) Influence of salts and $\mathrm{pH}$ on growth and activity of a novel facultatively alkaliphilic, extremely salt-tolerant, obligately chemolithoautotrophic sufuroxidizing Gammaproteobacterium Thioalkalibacter halophilus gen. nov., sp. nov. from south-eastern Siberian soda lakes. Extremophilies 12 (in press)

Berendes F, Gottschalk G, Heine-Dobbernack E, Moore ERB, Tindall BJ (1996) Halomonas desiderata sp. nov., a new alkaliphilic, halotolerant and denitrifying bacterium isolated from a municipal sewage works. Syst Appl Microbiol 19:158-167

Boltyanskaya YuV, Antipov AN, Kolganova TV, Lysenko AM, Kostrikina NA, Zhilina TN (2004). Halomonas campisalis, an obligatorily alkaliphilic, nitrous oxide-reducing denitrifier with a molybdenum cofactor-lacking nitrate reductase. Mikrobiologia (Moscow Engl Transl) 73:271-278

Boltyanskaya YuV, Kevbrin VV, Lysenko AM, Kolganova TV, Tourova TP, Osipov GA, Zhilina TN (2007) Halomonas mongoliensis sp. nov. and Halomonas kenyensis sp. nov., new haloalkaliphilic denitrifiers capable of $\mathrm{N}_{2} \mathrm{O}$ reduction, isolated from soda lakes. Microbiology (Moscow, Engl Transl) 76:739-747

Clifford D, Liu X (1993) Biological denitrification of spent regenerant brine using a sequencing batch reactor. Water Res 27:1477-1484

De Ley P, Cattoir H, Reynaerts A (1970) The quantitative measurement of DNA hybridization from renaturation rates. Eur $\mathrm{J}$ Biochem 12:133-142

Duckworth AW, Grant WD, Jones BE, Van Steenbergen R (1996) Phylogenetic diversity of soda lake alkaliphiles. FEMS Microbiol Ecol 19:181-191

Gries-Romijn-van Eck (1966) Physiological and chemical test for drinking water. NEN 1056, IY-2 Nederlandse Normalisatie Instituut Rijswijk

Jukes TH, Cantor CR (1969) Evolution of protein molecules. In: Munro HN (ed) Mammalian protein metabolism. Academic Press, New York, pp 21-123

Knowles R (1990) Acetylene inhibition technique: development, advantages, and potential problems. FEMS Symp 56:151-166

Kulp TR, Han S, Saltikov CW, Lanoil BD, Zargar K, Oremland RS (2007) Effects of imposed salinity gradients on dissimilatory arsenate reduction, sulfate reduction, and other microbial processes in sediments from two California soda lakes. Appl Environ Microbiol 73:5130-5137

Laemmli UK (1970) Cleavage of structural proteins during the assembly of the head of bacteriophage T4. Nature 227:680-685

Lane DJ (1991) 16S/23S rRNA sequencing. In: Stackebrandt E, Goodfellow $M$ (eds) Nucleic acid techniques in bacterial systematics. John Wiley \& Sons, Chichester, pp 115-177
Lowry OH, Rosebrough NJ, Farr AL, Randall RJ (1951) Protein measurement with the Folin phenol reagent. J Biol Chem 193:265-275

Marmur J (1961) A procedure for isolation of DNA from microorganisms. J Mol Biol 3:208-214

Marmur J, Doty P (1962) Determination of the base composition of deoxyribonucleic acid from microorganisms. J Mol Biol 5:109118

Mormile MR, Romine MF, Garcia MT, Ventosa A, Bailey TJ, Peyton BM (1999) Halomonas campisalis sp. nov., a denitrifying, moderately haloalkaliphilic bacterium. Syst Appl Microbiol 22:551-558

Oren A (1995) Uptake and turnover of acetate in hypersaline environments. FEMS Microbiol Ecol 18:75-84

Oren A (1999) Bioenergetic aspects of halophilism. Microbiol Mol Biol Rev 63:334-348

Oren A (2001) The bioenergetic basis for the decrease in metabolic diversity at increasing salt concentrations: Implications for the functioning of salt lake ecosystems. Hydrobiologia 466:61-72

Peyton BM, Mormile MR, Petersen JN (2001) Nitrate reduction with Halomonas campisalis: kinetics of denitrification at $\mathrm{pH} 9$ and $12.5 \% \mathrm{NaCl}$. Water Res 35:4237-4242

Pfennig N, Lippert KD (1966) Über das Vitamin $\mathrm{B}_{12}$-Bedürfnis phototropher Schwefelbakterien. Arch Microbiol 55:245-256

Romano I, Giordano A, Lama L, Nicolaus B, Gambacorta A. (2005) Halomonas campaniensis sp. nov., a haloalkaliphilic bacterium isolated from a mineral pool of Campania region, Italy. Syst Appl Microbiol 28:610-618

Sorokin DY, Kuenen JG (2005) Alkaliphilic chemolithotrophs from sodas lakes. FEMS Microbiol Ecol 52:287-295

Sorokin DY, Kuenen JG, Jetten M (2001) Denitrification at extremely alkaline conditions in obligately autotrophic alkaliphilic sulfuroxidizing bacterium Thioalkalivibrio denitrificans. Arch Microbiol 175:94-101

Sorokin DY, Zhilina TN, Spiridonova EM, Tourova TP, Lysenko AM (2006) Increased metabolic versatility of haloalkaliphilic bacteria belonging to the Alkalispirillum-Alkalilimnicola group from soda lakes. Extremophiles 10:213-220

Taher AG (1999) Inland saline lakes of Wadi El Natrun depression, Egypt. Int J Salt Lake Res 8:149-170

Van de Peer Y, De Wachter R (1994) TREECON for Windows: a software package for the construction and drawing of evolutionary trees for the Microsoft Windows environment. Comput Appl Biosci 10:569-570 